\title{
Spatio-temporal land-use changes in the Colima-Villa de Álvarez metropolitan area, and their relationship to floodings
}

\section{Myrna Lorena Pérez-González ${ }^{1, *}$, Lucia Capra Pedol'1, Norma Dávila-Hernández², Lorenzo Borselli ${ }^{3}$, Sara Solís-Valdez ${ }^{1}$, and Azalea Judith Ortiz-Rodríguez ${ }^{3}$}

\author{
${ }^{1}$ Centro de Geociencias, Universidad Nacional Autónoma de México, Campus Juriquilla, 76230, Querétaro, Mexico. \\ ${ }^{2}$ Instituto de Geografía, Universidad Autónoma del Estado de México, 50110, Toluca, Estado de México, Mexico. \\ ${ }^{3}$ Instituto de Geografía, Universidad Autónoma de San Luis Potosí, 78000, San Luis Potosí, S.L.P., Mexico. \\ *myrna@geociencias.unam.mx
}

\section{ABSTRACT}

Demographic growth and consequent land-use changes are considered one of the main factors causing inundations in many cities in developing countries. During the last decade, the city of Colima, Mexico, has suffered from an increase in flooding events. These episodes mostly occurred during tropical rainstorms associated to hurricanes (such as Jova in 2011, Manuel in 2013, and Patricia in 2015, all with average accumulated rainfall of $200 \mathrm{~mm}$ in $24 \mathrm{~h}$ ), as well as during shortduration, high-intensity rainfall events at the beginning of the rainy season. To define the mechanisms leading to the increased occurrence of floodings, a space-time analysis of land-use changes, coupled with the characterization of natural and urban soils, are presented here for the Colima metropolitan area. Three land-use categories were created: native land (N1), urban land (N4), and cultivated land (N5). Each of these categories has subcategories depending on vegetative cover and/ or level of urbanization. SPOT imagery acquired in 2005, 2009, and 2015 was classified to analyze the spatial and temporal changes in land use. Thirty-two soil samples representative of different land uses were analyzed to obtain their physical and chemical properties such as granulometry, bulk and particle densities, porosity, and organic matter content. Hydraulic conductivity tests were performed in situ using a drip-infiltrometer device.

The temporal and spatial analysis of SPOT images revealed that most changes in land use correspond to urban area and cultivated land, the former showing an increase and the latter a drastic decrease, especially towards the northern part of the city, where urban growth is evident for the 2005-2009 period. Analyzed soils from cultivated land have the highest permeability, and engineered soils correspond to the least permeable soils in the area; consequently, replacement of agriculture with housing has significant impacts on the rainfall-runoff process. These results indicate that as more permeable land area is substituted by disturbed urban soils, the infiltration capability will be reduced, leading to increasing flooding frequency in the Colima-Villa de Álvarez metropolitan area. To prevent and reduce the disruptive impact of inundation in the Colima metropolitan area, it is recommended to have adequate management of land-use change and to conserve the permeable areas around the city. In addition, it is necessary to revise the hydraulic infrastructure of the existing urban areas and to properly define the most suitable locations for future ones. Avoiding development in flood-prone areas through planning and zoning ordinances may reduce loss of life and damage to property.

Key words: flooding; land use; hydraulic conductivity; SPOT images; Colima; Mexico.

\section{RESUMEN}

El crecimiento demográfico, y por consiguiente los cambios de uso de suelo, se consideran entre los principales factores que pueden provocar el incremento de inundaciones en ciudades de países en desarrollo. Durante las últimas décadas en la Ciudad de Colima se ha incrementado la frecuencia con la que suceden inundaciones. Estos fenómenos ocurren mayormente durante tormentas tropicales asociadas a huracanes, como es el caso de Jova en 2011, Manuel en el 2013 y Patricia en el 2015, todas con lluvias acumuladas promedio de $200 \mathrm{~mm}$ en $24 \mathrm{~h}$. También suceden con tormentas intensas y de corta duración a comienzos de la temporada de lluvia. Para definir los mecanismos que aumentan la ocurrencia de este fenómeno, se presenta un análisis espacio-temporal del cambio de uso de suelo, junto con la caracterización de suelos naturales y urbanos para el área metropolitana de Colima.

Se definieron tres categorías principales de uso de suelo: Nativo (N1), Urbano (N4) y Agrícola (N5). Cada categoría tiene subcategorías dependiendo de la cobertura vegetal y/o nivel de urbanización. Imágenes SPOT adquiridas en 2005, 2009 y 2015 fueron clasificadas para analizar espacial y temporalmente los cambios de uso de suelo. Se analizaron treinta y dos muestras de suelo representativas de diferentes usos de suelo para obtener sus propiedades físicas y químicas, como granulometría, densidad aparente y de partícula, porosidad y contenido de materia orgánica. Pruebas de conductividad hidráulica in situ se hicieron usando un infiltrómetro por goteo.

Con base en el análisis temporal y espacial de las imágenes SPOT, se pudo detectar que la mayoría de los cambios de uso de suelo corresponden al área urbana y agrícola; la primera mostrando un incremento y la segunda una drástica disminución, especialmente hacia el norte donde el crecimiento urbano es evidente durante el periodo 2005-2009. Los suelos en las áreas agrícolas resultaron ser los más permeables, mientras 
que los suelos constituido por material compactado para construcción corresponden a los menos permeables en el área; por lo tanto, el reemplazo de las zonas agrícolas por zonas habitacionales tiene un impacto significativo en el proceso de lluvia-escurrimiento. Estos resultados indican que mientras más zonas permeables sean substituidas por suelos perturbados, la capacidad de infiltración será reducida, incrementando la frecuencia de inundaciones en el área metropolitana Colima-Villa de Álvarez.

Para prevenir y reducir el impacto destructivo de las inundaciones en el área metropolitana de Colima, se recomienda tener un manejo adecuado del cambio de uso de suelo y conservar las superficies permeables alrededor de la ciudad. Adicionalmente, es necesario revisar la infraestructura hidráulica existente de las zonas urbanas y definir los sitios adecuados para las futuras. Evitar desarrollos urbanos en zonas susceptibles a inundación a través de la buena planificación y la reglamentación, podría reducir las pérdidas de vidas y daños materiales producto de estos eventos.

Palabras clave: inundaciones; uso de suelo; conductividad hidráulica; imágenes SPOT; Colima; México.

\section{INTRODUCTION}

Most of the world's population is concentrated in large cities. Demographic increases have forced land-use changes from natural soils to cultivated and then to urban areas. These changes can induce a decrease in infiltration rates, promoting flooding (Pathiran et al., 2014), and can impact the regional climate by modifying the surface energy and water balances (Foley et al., 2005).

Mexico is highly exposed to hydrometeorological disasters. In 2013, hurricanes Manuel and Ingrid hit both sides of the country, affecting $77 \%$ of the territory, producing landslides and floodings in many states (Pedroza-Acuña, et al., 2015). Pedroza-Acuna et al. (2015) observed that land-use changes in urban areas significantly increase precipitation depth, and concluded that land-use planning is fundamental to reducing flooding risks in Mexico.

Colima is one of the Mexican states most susceptible to natural disasters (Padilla and de la Parra, 2015). It is located in the centralwestern coast of the country on a complex orographic and hydrographic system. Most of the region consists of volcanic rocks from the Colima Volcanic Complex (CVC). The Volcán de Colima is the youngest edifice of the CVC and is the most active volcano in Mexico (Capra et al., 2014). The city of Colima is settled on top of a volcaniclastic apron made of debris avalanche deposits originated from the collapse of the volcano approximately 7500 years ago (Luhr and Prestegaard, 1988; Cortés et al., 2005). The debris avalanche deposits correspond to a mixture of meter-sized andesitic clasts in a poorly sorted coarsegrained matrix, from gravel to clay (Roverato and Capra, 2013). Due to this heterogeneous texture, the soil is poorly developed and cultivated soils are made of improved crop land.

The metropolitan area of Colima-Villa de Álvarez (Figure 1) has been qualified with no risk of inundation in the case of moderate precipitation events (less than $20 \mathrm{~mm}$ ) in the flood risk map of National Center for Disaster Prevention (CENAPRED, 2015). However, slightly higher precipitation causes inundation; such a rainfall occurred on 27 July, 2015, with $25 \mathrm{~mm}$ precipitation depth in less than one hour, producing urban floodings and hail, fallen trees, and warning of lahars affecting the northern part of the city (Periódico Ecos de la Costa, 2015). More common examples of rains causing floodings are extraordinary rainfalls such as hurricanes: Jova on October $11^{\text {th }}, 2011$ $(174 \mathrm{~mm} / 10 \mathrm{~h})$, Manuel on November $6^{\text {th }}, 2013(117 \mathrm{~mm} / 4 \mathrm{~h})$, and
Patricia on October 23 ${ }^{\text {th }}, 2015(237 \mathrm{~mm} / 17 \mathrm{~h})$ (based on CONAGUAEMA data, $h t t p: / / s m n 1$.conagua.gob.mx/emas). These very intense storms (Figure 2) caused extensive damage including human casualties.

As observed in other main cities in Mexico (e.g., Eakin, 2010; Perevochtchikova, 2010), Colima experimented an important urban expansion during the last decade around its periphery, especially towards the north (SEMARNAT, 2000; Gobierno Municipal de Colima, 2012). Given this scenario, the purpose of this paper is to better understand how land-use change increases flooding in the urban area of Colima. Particularly, we will focus on land-use change during the last 10 years based on a spatio-temporal analysis of SPOT images, and the analysis of soils from different land uses to determine their physical and chemical characteristics, and their hydrological behavior based on in situ infiltration tests.

\section{METHODOLOGY}

\section{Study area}

The metropolitan area of Colima-Villa de Álvarez is located at approximately $500 \mathrm{~m}$ a.s.l. A basin analysis shows that the urban area is included in a $52 \mathrm{~km}^{2}$ hydrological basin that drains from the lowest slope of the Volcán de Colima. This basin was delineated using the basin tool in ArcMap 10.1, with a Digital Elevation Model (DEM) of $30 \mathrm{~m}$ resolution (INEGI, 2015). Inside this basin, a target area was selected in the northern part of the metropolitan area (Figure 1), where the greatest urban growth occurred during the past years. This area has native, cultivated, and urban surfaces and may provide significant information for land-use evolution (Yang and Zang, 2015). For the target area, a land-use classification, based on direct observations, was performed. In particular, the land use was subjectively classified using a 2015 Landsat image extracted from Google Earth, where different land uses were easily recognizable from surface characteristics. Each polygon drawn in the classification process was then visited in the field to verify the assigned surface category (Figure 3 ). Three land-use categories were created: native land (N1), urban land (N4), and cultivated land (N5). Each of these categories has subcategories depending on vegetative cover and/or level of urbanization (Table 1; Figure 3). The target area was then used to validate the image segmentation of the 2005, 2009, and 2015 SPOT images to define the spatial and temporal variation of land use of the entire basin. For each land-use category, soil samples were collected to analyze their physical and chemical characteristics and to perform in situ infiltration tests (Figure 4, and Tables 2 and 3). Figure 5 illustrates the steps of the methodological procedures.

\section{Spatial and temporal changes in land use}

To evaluate the spatial and temporal changes in land-use for the study area, three 1A level SPOT images of the dry season (without any previous geometric process) were selected to ensure the most similar image reflectance. The processed images are SPOT 4, 5, and 6 taken on May 2005, March 2009, and January 2015, respectively.

Radiometric and atmospheric corrections for the three $1 \mathrm{~A}$ images were made using ENVI 5.1 software. Georeferentiation was performed in the IMAGINE AutoSync Workstation tool of ERDAS IMAGINE 2014 software using an orthophoto of the study area as a base image. The projected coordinate system used is the WGS 1984, UTM zone $13 \mathrm{~N}$. An average of 20 points were selected for each image, looking for a root mean square error (RMSE) of less than 3 on each point. For the performed analyses, the RMSE ranged from 0.24 to1.9.

Images were segmented to elaborate a land-use classification for the target area, using as training data the polygon of the land-use classification described above. This classification was performed only for 


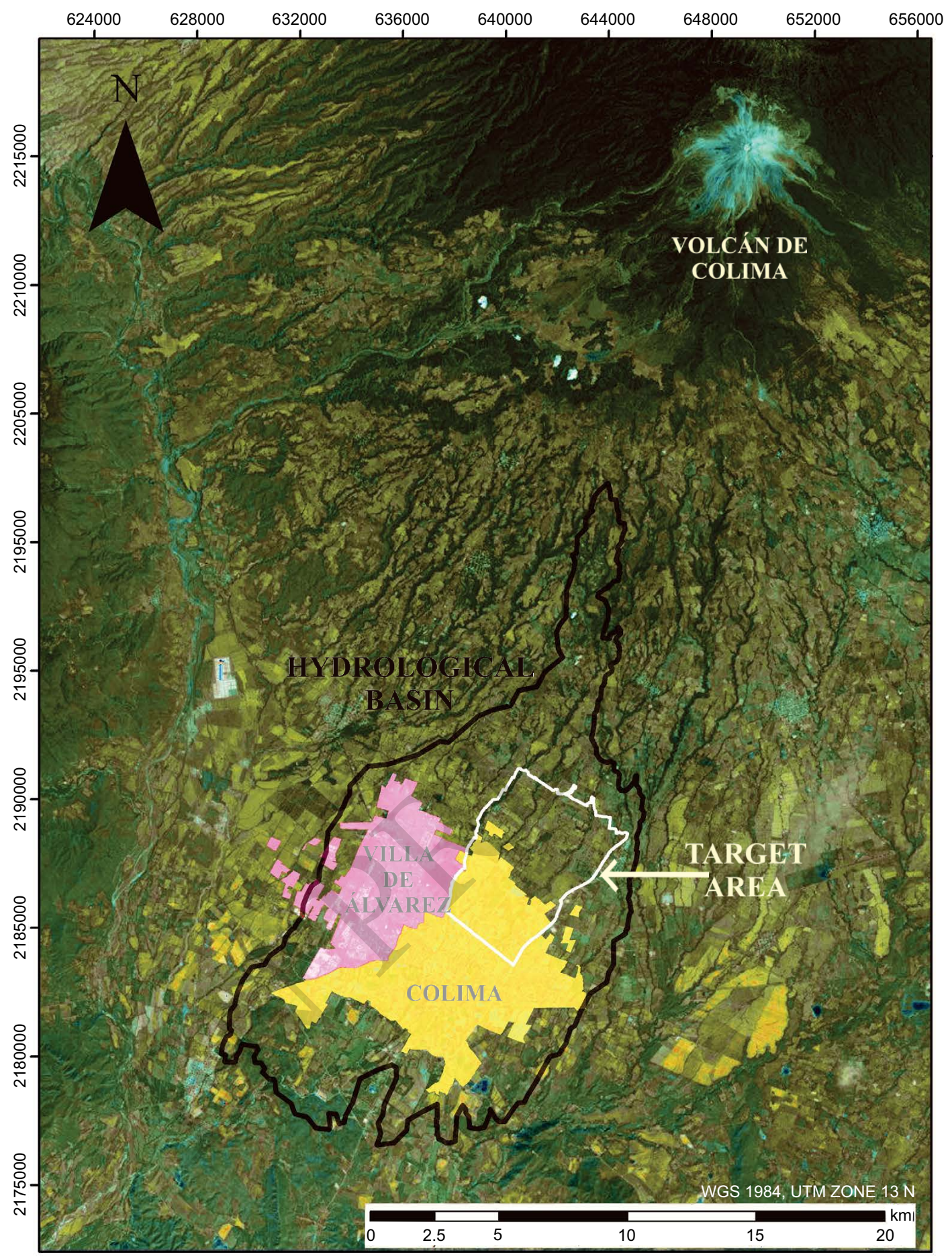

Figure 1. Landsat image showing the extent of the metropolitan area of Colima and Villa de Álvarez, included in the same hydrological basin (black line), which is the object of this study and the target area (white line) used as a buffer for land-use classification, sampling, and infiltration tests.

urban land (N4), cultivated land (N5) and for native lands with trees (N1A) and grazing (N1P) land-uses. The land-use classification was then extended to the entire basin. The RMSE values of the supervised image classification were between 0.24 to 1.90 .

\section{Physical-chemical properties of soils}

A total of 32 soil samples were collected in the target area and analyzed to determine their physical properties according to the meth-
Table 1. Land-use categories defined for the target area.

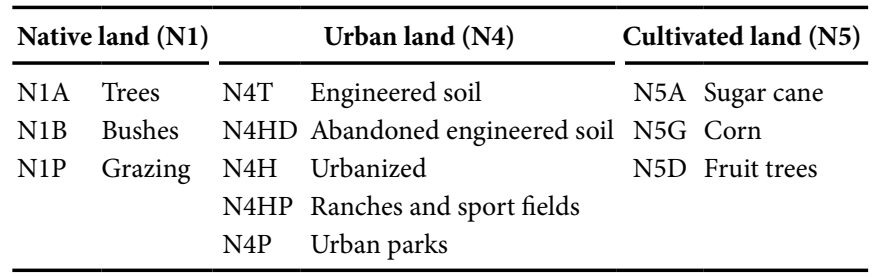


Table 2. Methods used to determine the reported physical and chemical properties of samples soils.

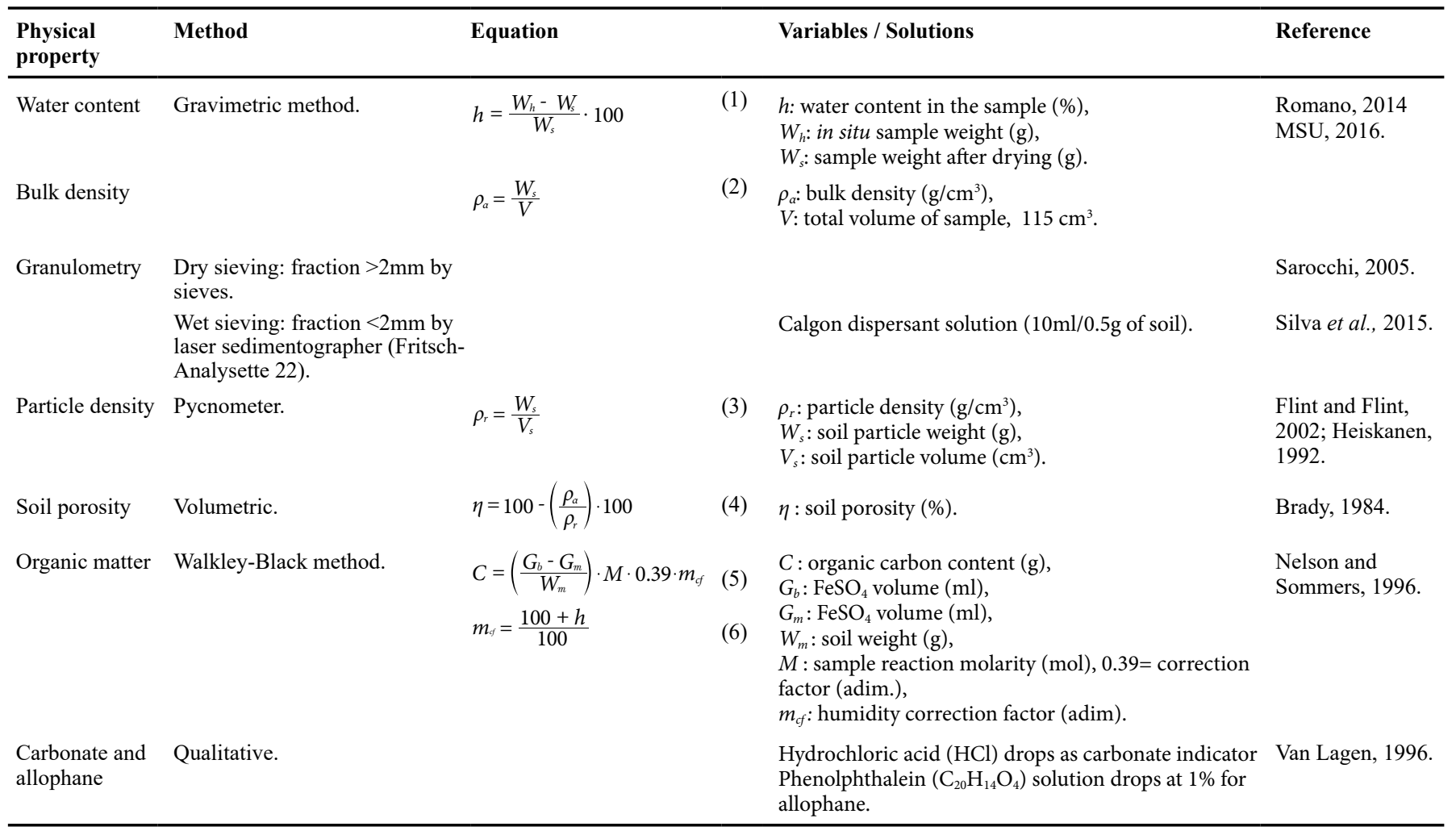

odology proposed by the USDA $(1999,2008)$ and Landscape for Life Organization (2016). Seventeen of these samples were extracted using a $115 \mathrm{~cm}^{3}$ iron sampling cylinder (Figures $4 \mathrm{a}$ and $\mathrm{b}$ ) in order to get unaltered soil samples. For poorly developed soils with depths of less than $15 \mathrm{~cm}$ (Figure 6), the samples were collected with a shovel. Samples were carefully packed in plastic film to keep the in situ water moisture. Table 2 shows the analytical methods and the equations (1-6) used to determine bulk density $\left(\rho_{\alpha}\right)$ and water content $(\mathrm{h})$, granulometry, particle density $\left(\rho_{r}\right)$, porosity $(\eta)$, organic matter $(\mathrm{Om})$, and carbonate and allophane qualitative estimation.

\section{In situ infiltration measurements}

Saturated hydraulic conductivity $\left(K_{s}\right)$ is an important soil property, especially for surface runoff and infiltration processes. It can be obtained by field or laboratory methods; however, the measurement techniques are expensive and time consuming. Here, the $K_{s}$ was estimated based on a noninvasive field infiltration test. The model was proposed by Ekhmaj and Abdulaziz (2008) and it is based on the equation proposed by Wooding (1968) where discharge rate and a steady saturated radius are used to determine the saturated hydraulic conductivity:

$$
q=\frac{Q}{\pi r_{s}^{2}}=k_{s}+\frac{4 K_{s}}{\pi \alpha} \frac{1}{r_{s}}
$$

The left side of Equation 7 explains the gravity contribution to the flow, while the right side represents the capillarity and geometry of the source. In this equation $q$ is the flux discharge per unit area $\left(\mathrm{l} / \mathrm{h} / \mathrm{cm}^{2}\right) ; Q$, the flux discharge $(1 / \mathrm{h}) ; r_{s}$, the saturation radius of the water mirror when it becomes stable, i.e., ponded area $(\mathrm{cm}) ; K_{s}$, the saturated hydraulic conductivity $(\mathrm{cm} / \mathrm{h})$; and $\alpha$ is a constant relative to soil sorptivity, a property describing the rate of reduction in conductivity with matric head.
The soil moisture value is related to $\alpha$ as:

$$
\frac{K_{s}}{\alpha} \approx \frac{b S^{2}}{\left(\theta_{f}-\theta_{i}\right)}
$$

where $\theta_{i}$ is the initial soil moisture (\%), $\theta_{f}$ the final soil moisture (\%), $S$, the sorptivity $\left(\mathrm{cm} / \mathrm{h}^{1 / 2}\right)$, and $b$, the shape factor. The value of $b$ is bounded between $1 / 2$ and $\pi / 4$. White and Sully (1987) suggested that $b=0.55$ is a practical value for most soils.

To solve Equation 8 for $K_{s}$, it is necessary to measure the initial $\left(\theta_{i}\right)$

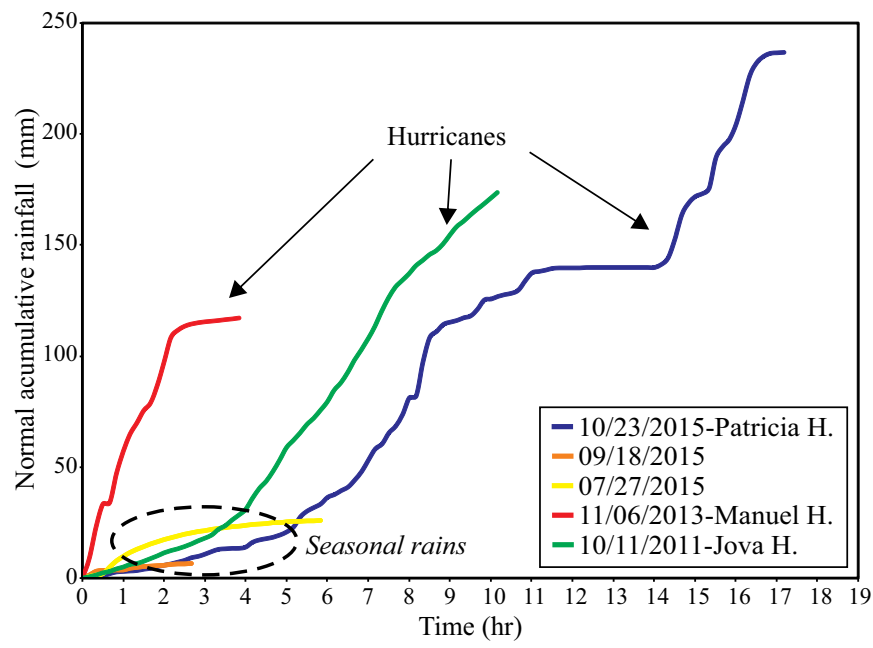

Figure 2. Cumulated curves of some rainfall events recorded at the Meteorological Station of Colima City (Comisión Nacional del Agua), including events related to hurricanes. 


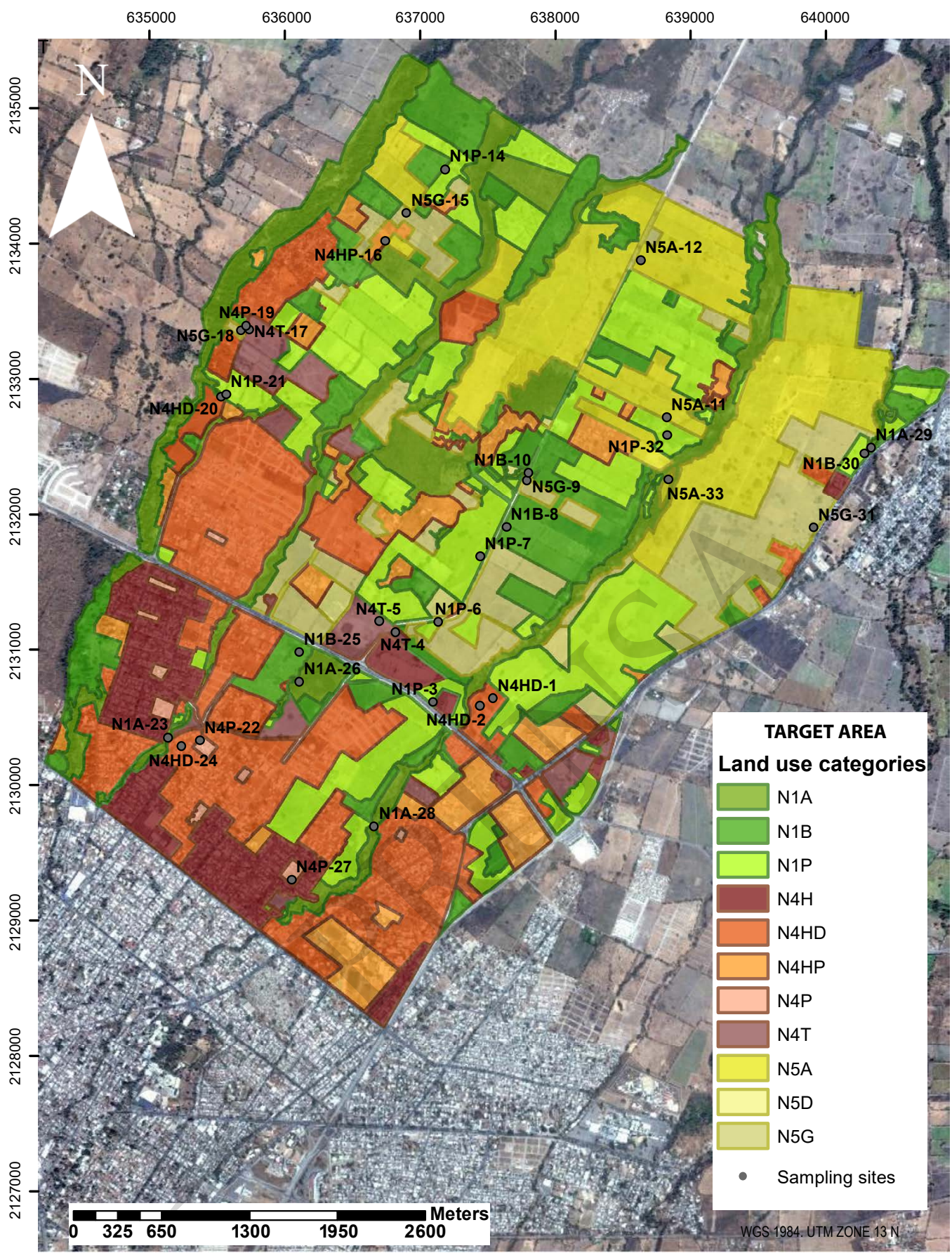

Figure 3. Land-use classification map for target area and location of sampled sites. An explanation of land-use classification labels can be found in Table 1.

and final $\left(\theta_{f}\right)$ soil moisture (Borselli et al., 2001). These values were obtained using a time-domain reflectometer (Turf-Tec International, 2016). Finally, the $K_{s}$ is obtained by equalizing the left term of Equation 7 with the equation proposed by Borselli et al. (2012):

$$
\frac{Q}{\pi r_{s}^{2}}=\frac{K_{s}}{10}+\frac{4 \frac{K_{s}}{10} G \frac{\Delta_{\theta}}{10}}{\pi} \frac{1}{r_{s}}
$$

where $G$ represents the capillarity depth, which can be expressed as:

$$
G=\frac{1}{\alpha}
$$

Finally, an algorithm in Excel was implemented with the solver tool, and $K_{s}$ and $G$ area obtained by iteration from Equation 9 .

The in situ infiltration measurements were made using a portable drip-infiltrometer. This drip-infiltrometer consists of three peristaltic pumps each connected by rubber hoses to a water container (Figure $4 \mathrm{c}$ ). Each of the pumps supplies a different flow volume $\left(\mathrm{Q}_{1}=1.56 \mathrm{l} / \mathrm{h}, \mathrm{Q}_{2}=2.71 \mathrm{l} / \mathrm{h}\right.$, and $\left.\mathrm{Q}_{3}=7.76 \mathrm{l} / \mathrm{h}\right)$. Pictures of the ponded area were taken every minute perpendicularly to the ground surface using a tripod, including a metric scale bar. The soils tests were performed in three sets of 15 minutes, one for each flow discharge, Q1, Q2, and Q3. 

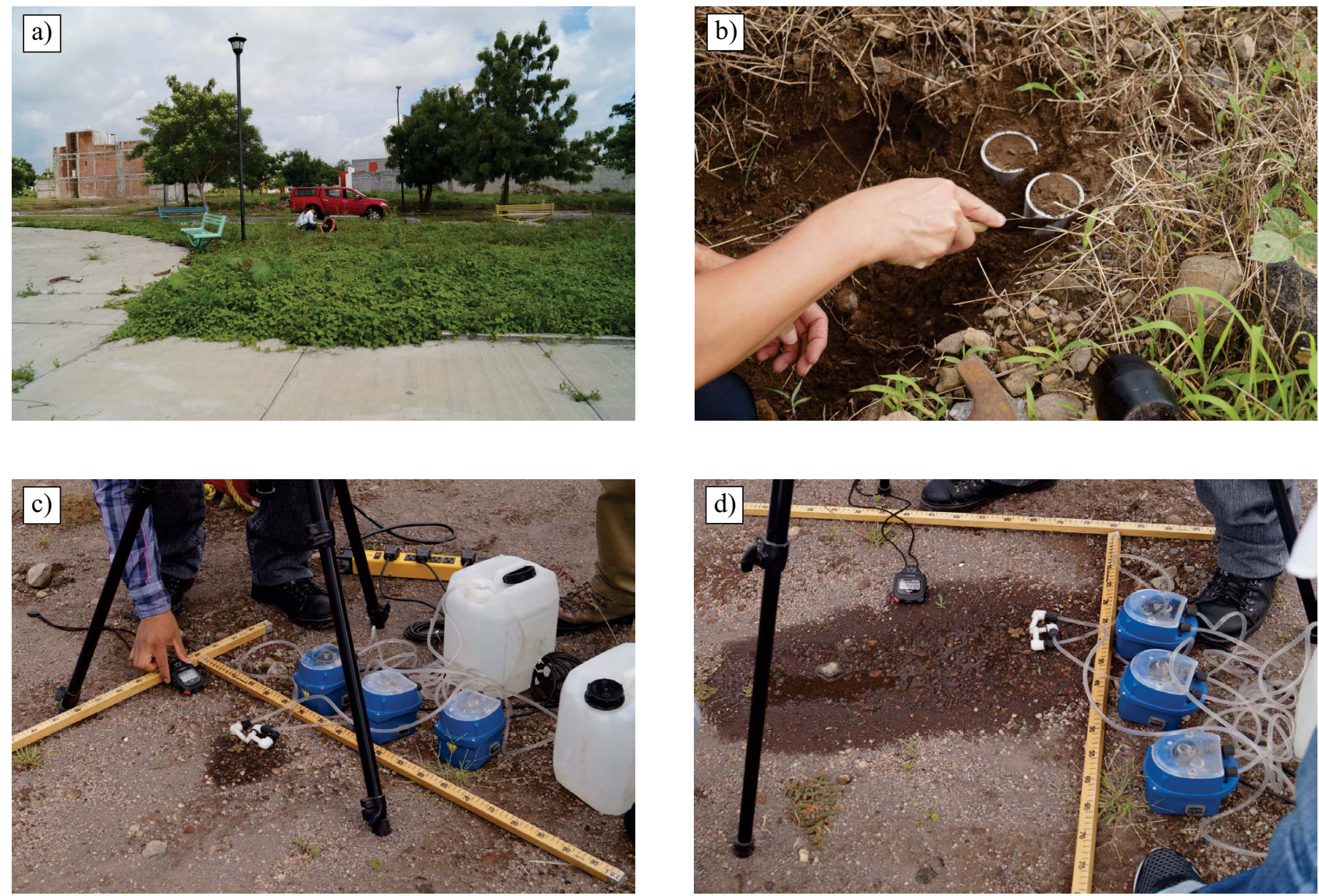

Figure 4. Pictures showing some of the procedures used in the present work. a) Example of sampling in an urban park using a $115 \mathrm{~cm}^{3}$ iron cylinder (shown in b). c) Initial and d) final step of the infiltration test with the drip infiltrometer.

The ponded area was calculated excluding the capillarity portion, which is the wet area where the water had already infiltrated (Figure 4d). This image process was made using Corel-Photo-Paint $\mathrm{X} 4$ software. Once the area was defined, Image J software was used to calculate the surface of the ponded area needed to extrapolate the hydraulic conductivity.

Finally, the $K_{s}$ was estimated using as input data in the solver the initial and final moisture, discharge rate, and ponded area, from which an optimized radius is calculated at each time step. Results are shown in Table 4.

\section{RESULTS}

\section{Physical and chemical properties of soils by land-use category}

Based on land-use classification, representative soil samples were analyzed to obtain their physical and chemical characteristics to be correlated with their infiltration properties. In particular, unaltered lands (native) were distinguished by the presence of trees (N1A), bushes (N1B), and grazing (N1P). For altered lands (cultivated and urban), samples were obtained from agricultural land (N5, A for sugar cane and $\mathrm{G}$ for corn), engineered soil (native soil completely removed and replaced with compacted sand: N4T when in construction stage, and N4HD when partially abandoned and with incipient vegetative cover), rural altered land (e.g., ranches, N4HP), urban park area (N4P). Table 3 presents a summary of the physical and chemical characteristics of the analyzed soils.

\section{Granulometric analysis}

The particle-size distribution shows that all samples consist of more than $88 \%$ sand. The silt fraction is up to $8 \%$ and clay reaches a maximum of $3 \%$ (Figure 7 ).

\section{Bulk $\left(\rho_{a}\right)$ and particle density $\left(\rho_{r}\right)$, water content $(h)$, porosity $(\eta)$,} organic matter $(\mathrm{Om})$, and allophane content

Samples from native land show highly variable properties. Bulk density varies from a minimum of 1.00 to a maximum of $1.50 \mathrm{~g} / \mathrm{cm}^{3}$, while porosity varies from 6 to $56 \%$. Water content varies from 7 to $28 \%$ and organic matter content from 0.16 to $11 \%$ (Table 3). Most of the analyzed samples contain allophane and few of them have carbonate. Samples from native land for grazing (N1P) show distinctive characteristics, with the lowest porosity values within the native land category, which ranged from 29 to $41 \%$.

Samples from cultivated lands have more homogeneous characteristics, with bulk density around $1.00 \mathrm{~g} / \mathrm{cm}^{3}$, porosity of $55 \%$, water content between 28 and $18 \%$, and organic matter values of $2 \%$, with two samples that show values up to $11 \%$. Almost all these samples contain allophane, but none of them contain carbonates.

Samples from urban lands represent the most heterogeneous group. The engineering soils show the lowest value of porosity (6\%) and the highest bulk density $\left(1.52 \mathrm{~g} / \mathrm{cm}^{3}\right.$, sample N4T-4). Samples from abandoned engineered soils (N4HD) show more homogeneous values with a lower average bulk density of $1.30 \mathrm{~g} / \mathrm{cm}^{3}$, and porosity around $30 \%$. The highest porosity and one of the lowest bulk density values were found in samples from urban parks ( $37 \%$ and $8.00 \mathrm{~g} / \mathrm{cm}^{3}$, respectively). 
Table 3. Summary of some physical and chemical characteristics of the soils by land-use category.

\begin{tabular}{|c|c|c|c|c|c|c|c|c|c|c|}
\hline \multirow[b]{2}{*}{ Sample } & \multicolumn{3}{|c|}{ Granulometry } & \multicolumn{5}{|c|}{ Soil characteristics } & \multicolumn{2}{|c|}{ Qualitative tests } \\
\hline & Clay & $\begin{array}{l}\text { Silt } \\
\text { wt (\%) }\end{array}$ & Sand & $\begin{array}{c}\text { Water content } \\
h(\%)\end{array}$ & $\begin{array}{l}\text { Bulk density } \\
\rho_{a} \mathrm{~g} / \mathrm{cm}^{3}\end{array}$ & $\begin{array}{l}\text { Particle density } \\
\rho_{r} \mathrm{~g} / \mathrm{cm}^{3}\end{array}$ & $\begin{array}{c}\text { Porosity } \\
\eta(\%)\end{array}$ & $\begin{array}{c}\text { Organic matter } \\
\operatorname{Om}(\%)\end{array}$ & Carbonate & Allophane \\
\hline \multicolumn{11}{|c|}{ Native land } \\
\hline N1A-23 & 0.57 & 1.13 & 98.29 & nd & nd & nd & nd & 0.29 & - & $\mathrm{X}$ \\
\hline N1A-26 & 0.73 & 3.32 & 95.95 & nd & nd & nd & nd & 5.10 & - & $\mathrm{X}$ \\
\hline N1A-28 & 1.97 & 7.15 & 90.88 & nd & nd & nd & nd & 2.19 & - & - \\
\hline N1A-29 & 0.9 & 4.78 & 94.31 & 15.07 & 1.12 & 2.21 & 49.33 & 5.34 & $\mathrm{X}$ & - \\
\hline N1B-8 & 1.64 & 3.16 & 95.2 & 16.34 & 1.03 & 2.01 & 48.94 & 3.05 & - & $\mathrm{X}$ \\
\hline N1B-10 & 1.05 & 2.25 & 96.7 & nd & nd & nd & nd & 2.12 & - & $\mathrm{X}$ \\
\hline N1B-25 & 0.75 & 2.33 & 96.92 & 6.69 & 1.49 & 2.05 & 27.37 & 0.11 & $\mathrm{X}$ & - \\
\hline N1B-30 & 1.18 & 3.38 & 95.44 & nd & nd & nd & nd & 4.20 & - & - \\
\hline N1P-3 & 1.77 & 4.75 & 93.48 & nd & nd & nd & nd & 1.02 & $\mathrm{X}$ & X \\
\hline N1P-6 & 2.16 & 5.37 & 92.47 & nd & nd & nd & nd & 3.28 & - & $\mathrm{X}$ \\
\hline N1P-7 & 1.31 & 2.39 & 96.29 & nd & nd & nd & nd & 1.54 & - & $\mathrm{X}$ \\
\hline N1P-14 & 1.37 & 3.78 & 94.86 & 15.99 & 1.29 & 1.82 & 29.23 & 3.75 & - & $\mathrm{X}$ \\
\hline N1P-21 & 1.35 & 4.85 & 93.8 & nd & nd & nd & nd & 3.18 & $\mathrm{X}$ & $\mathrm{X}$ \\
\hline N1P-32 & 1.51 & 5.41 & 93.08 & 17.15 & 1.30 & 2.19 & 40.67 & 2.69 & - & - \\
\hline \multicolumn{11}{|c|}{ Cultivated land } \\
\hline N5A-11 & 2.8 & 8.26 & 88.95 & nd & nd & nd & nd & 10.71 & - & X \\
\hline N5A-12 & 0.85 & 2.04 & 97.1 & nd & nd & nd & nd & 2.79 & - & $\mathrm{X}$ \\
\hline N5A-33 & 1.28 & 5.03 & 93.69 & 27.76 & 0.99 & 2.25 & 55.92 & 7.51 & - & - \\
\hline N5G-9 & 0.54 & 1.14 & 98.32 & 15.62 & 1.03 & 2.35 & 56.1 & 2.92 & - & $\mathrm{X}$ \\
\hline N5G-15 & 0.77 & 2.17 & 97.06 & nd & nd & nd & nd & 2.35 & - & $\mathrm{X}$ \\
\hline N5G-18 & 0.67 & 1.35 & 97.98 & nd & nd & nd & nd & 2.24 & - & $\mathrm{X}$ \\
\hline N5G-31 & 0.94 & 2.65 & 96.41 & 18.45 & 1.00 & 2.19 & 54.3 & 9.88 & - & - \\
\hline \multicolumn{11}{|c|}{ Urban land } \\
\hline N4HP-16 & 1.21 & 4.84 & 93.94 & 20.44 & 1.32 & 1.57 & 15.65 & 4.94 & - & $\mathrm{X}$ \\
\hline N4T-4 & 1.74 & 3.59 & 94.67 & 7.07 & 1.52 & 1.61 & 5.53 & 0.21 & - & $\mathrm{X}$ \\
\hline N4T-5 & 2.4 & 7.16 & 90.44 & nd & nd & nd & nd & 0.16 & - & $\mathrm{X}$ \\
\hline N4T-17 & 0.84 & 1.71 & 97.44 & nd & nd & nd & nd & 1.34 & $\mathrm{X}$ & $\mathrm{X}$ \\
\hline N4P-19 & 3.18 & 4.55 & 92.27 & 13.69 & 1.14 & 1.80 & 36.55 & 2.48 & - & $\mathrm{X}$ \\
\hline N4P-22 & 1.65 & 3.04 & 95.31 & 8.09 & 1.20 & 2.21 & 45.6 & 2.10 & - & $\mathrm{X}$ \\
\hline N4P-27 & 2.12 & 4.15 & 93.73 & nd & nd & nd & nd & 3.40 & $\mathrm{X}$ & - \\
\hline N4HD-1 & 2.2 & 2.82 & 94.98 & 10.59 & 1.19 & 1.85 & 35.74 & 0.98 & - & - \\
\hline N4HD-2 & 1.61 & 4.46 & 93.93 & 11.56 & 1.30 & 1.92 & 32.48 & 2.16 & - & $\mathrm{X}$ \\
\hline N4HD-20 & 1.86 & 4.58 & 93.56 & 20.20 & 1.37 & 1.94 & 29.28 & 2.00 & - & $\mathrm{X}$ \\
\hline N4HD-24 & 1.95 & 5.56 & 92.49 & 11.30 & 1.40 & 2.12 & 33.94 & 2.08 & - & $\mathrm{X}$ \\
\hline
\end{tabular}

Note. nd: not determined; X: Positive to the test; -: Negative to the test. Sample code identify land-use category (see Table 1) and sample number.

In summary, cultivated lands are the most homogenous type, while native and urban lands could be highly variable. Cultivated lands have very low bulk densities related to relative high organic matter content. They have the highest porosity values as a result of mechanical loosening during the cultivation process. In contrast, samples from grazing areas are the ones with the highest bulk density and the lowest porosity values. These properties differences play an important role in water infiltration as confirmed by the infiltration tests.

\section{Soil permeability}

The hydraulic conductivity $\left(K_{s}\right)$ values obtained with the dripinfiltrometer (Table 4), varied from 32.16 to $0.47 \mathrm{~mm} / \mathrm{h}$. In the case of native lands, the $K_{s}$ has the highest value in the N1A category (trees). It drastically decreases to $5 \mathrm{~mm} / \mathrm{h}$ for bush lands and to a minimum of $0.50 \mathrm{~mm} / \mathrm{h}$ for grasslands used for grazing. Cultivated lands have a $K_{s}$ value of $24.75 \mathrm{~mm} / \mathrm{h}$. For urban surfaces, the park areas show the highest $K_{s}$ values for this category $(10 \mathrm{~mm} / \mathrm{h})$, which drastically decreases to $0.80 \mathrm{~mm} / \mathrm{h}$ for engineering soils. Stone paved roads (N4E) were also tested, even if they do not represent a land-use category at the scale of this study, obtaining a value of almost $2 \mathrm{~mm} / \mathrm{h}$. Thus, grazing lands are the least permeable among native lands (similar to engineering soils), whereas cultivated areas show one of the highest values (similar to natural lands with trees). Even if samples are up to $88 \%$ sand, the $K_{s}$ values obtained largely reflect their vegetative cover and degree of disturbance. Allophane content can also be an explanation for lower $K_{s}$ values, which are not expected for sandy soils. Finally, values calculated here were in the range of those reported previously for similar land uses (Christianson et al., 2012; Ferrer-Julia et al., 2003).

\section{Land-use change}

From 2005 to 2009 the urban area in the target zone has increased by $8 \%$ while, from 2009 to 2015 , the increase was of $5 \%$, with a total urban growth from 2005 to 2015 of $13 \%$. Native soils and cultivated 


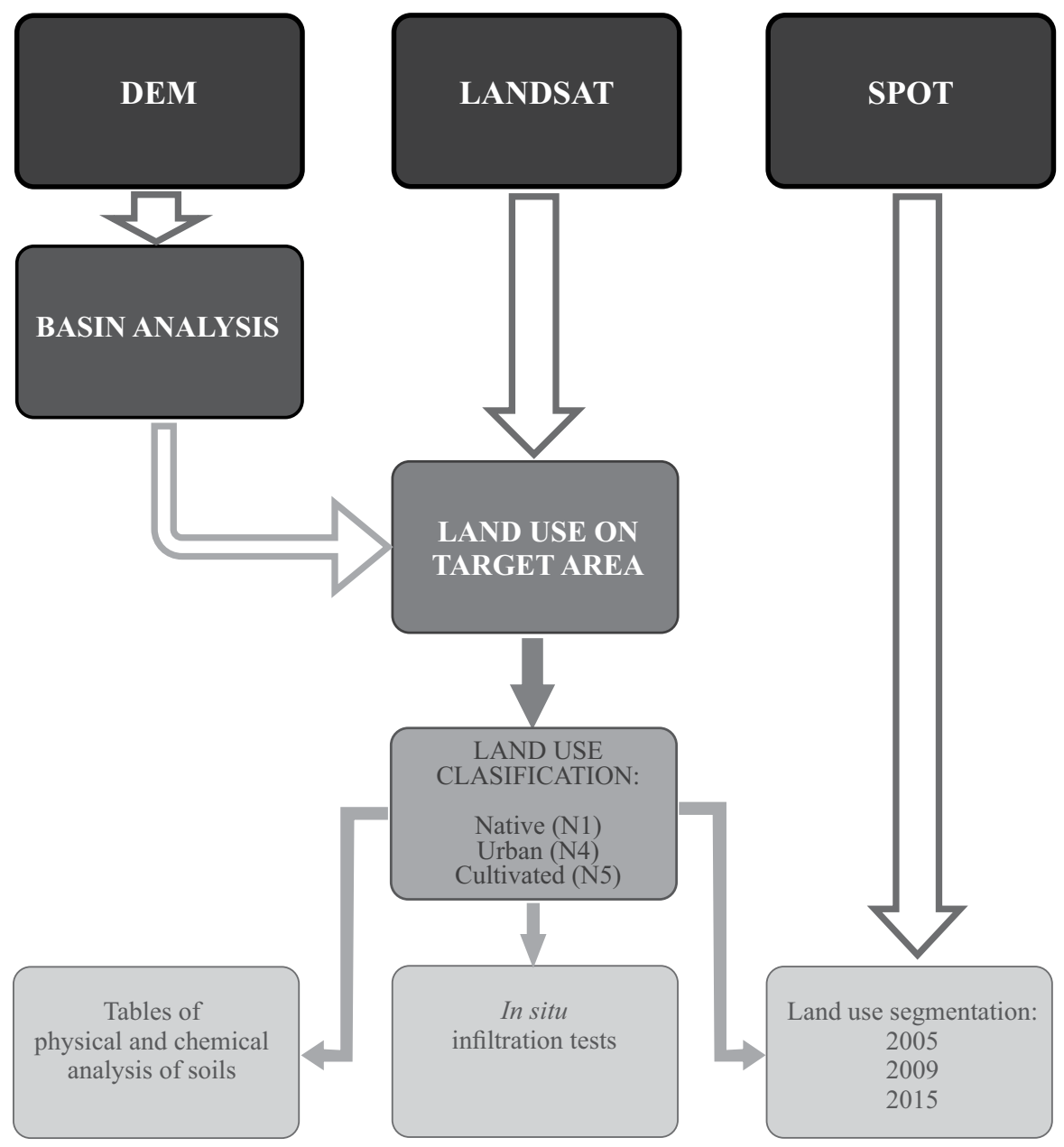

Figure 5. Flow diagram summarizing the methodology used in the present work. See Table 2 for analytical methods used for soil characterization.
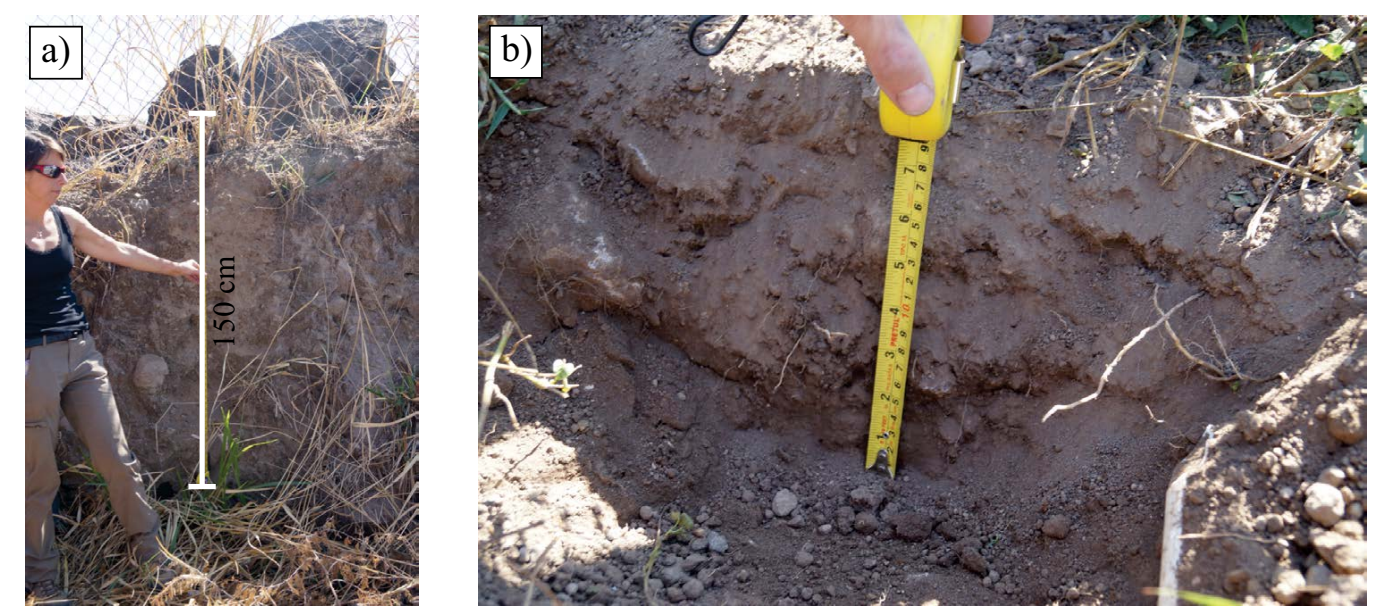

Figure 6. Example of the poorly developed volcanic soils studied in the area. a) Debris avalanche deposit consisting of poorly sorted, $\mathrm{cm}$-sized clasts embedded in a sandy matrix. b) Incipient soil developed on the debris avalanche deposit. 
Table 4. Hydraulic conductivity $\left(K_{s}\right)$ and capillarity depth $(G)$ for the main land-use categories.

\begin{tabular}{|c|c|c|c|c|c|c|c|}
\hline Land-use & $\begin{array}{c}\boldsymbol{K}_{s} \\
(\mathrm{~mm} / \mathrm{h})\end{array}$ & RMSE & $\underset{(\mathrm{mm})}{\boldsymbol{G}}$ & Land-use & $\begin{array}{c}\boldsymbol{K}_{s} \\
(\mathrm{~mm} / \mathrm{h})\end{array}$ & RMSE & $\underset{(\mathrm{mm})}{\boldsymbol{G}}$ \\
\hline Trees (N1A) & 32.16 & 0.71 & 769.41 & Engineered soil (N4T) & 0.84 & 2.94 & 670.05 \\
\hline Bushes (N1B) & 5.48 & 1.11 & 2000.00 & Urban parks (N4P) & 10.33 & 2.87 & 1441.78 \\
\hline Grazing (N1P) & 0.47 & 3.72 & 1333.59 & Stone paved road (N4E) & 1.92 & 0.37 & 2000.00 \\
\hline Cultivated (N5A-G) & 24.75 & 3.88 & 20.03 & & & & \\
\hline
\end{tabular}

soils also changed during the considered period. Apparently, cultivated lands decreased $12 \%$ from 2005 to 2015 , while native areas (all N1A and $\mathrm{B}$ land uses) decreased only $4 \%$ and grazing lands increased by 3\% (Figure 8a, Table 5).

Considering the entire basin, where most of the land use is native or cultivated, natural lands increased by $9 \%$ from 2005 to 2015 . Urban land, which represents $\sim 28 \%$ of the entire basin, changed by $2 \%$ from 2005 to 2009 with practically no appreciable changes from 2009 to 2015. In contrast, cultivated lands showed a drastic decrease of $10 \%$ during this period that correlates with a similar increase in native lands (Figure 8b, Table 6).

\section{DISCUSSION}

The land-use change phenomenon has been widely discussed, demonstrating that change in land use in developing countries modifies rainwater infiltration, increasing disasters associated to flooding (e.g., Gregory et al., 2006; Dong-Shen et al.,2008). In fact, land-use change, such as replacement of agriculture with housing, represents significant impacts on the rainfall runoff process. Residential construction also causes an increase in impervious areas, such as rooftops, driveways, and roads (Leopold, 1968).

On the basis of the physical and chemical characteristics of the analyzed soil samples representative of the different land uses classified here, and considering the $K_{s}$ values obtained from field tests, a preliminary evaluation between land-use change from 2005 to 2015 and flooding increase in the urban area of Colima is proposed. Several works pointed out that multiple infiltration tests are needed to appropriately estimate $K_{s}$ of disturbed or altered soils (e.g., Woltemade, 2010; Christianson et al., 2015). Here, we estimated the $K_{s}$ of each land use based only on one measurement. Nevertheless, by coupling these values with the physical and chemical characteristics of the analyzed sample, some observations about infiltration behaviors can be made.

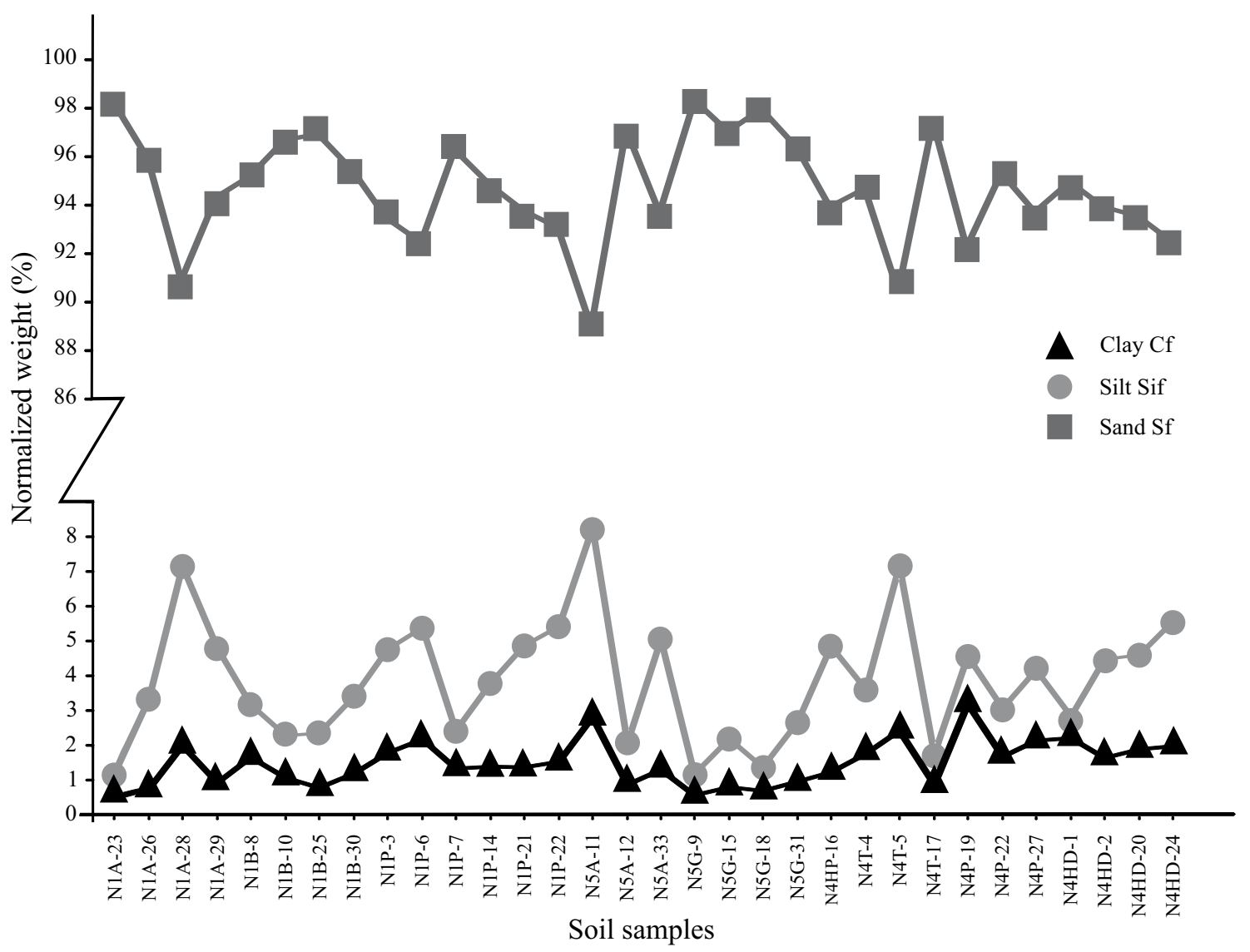

Figure 7. Particle-size distribution in analyzed soil samples. 

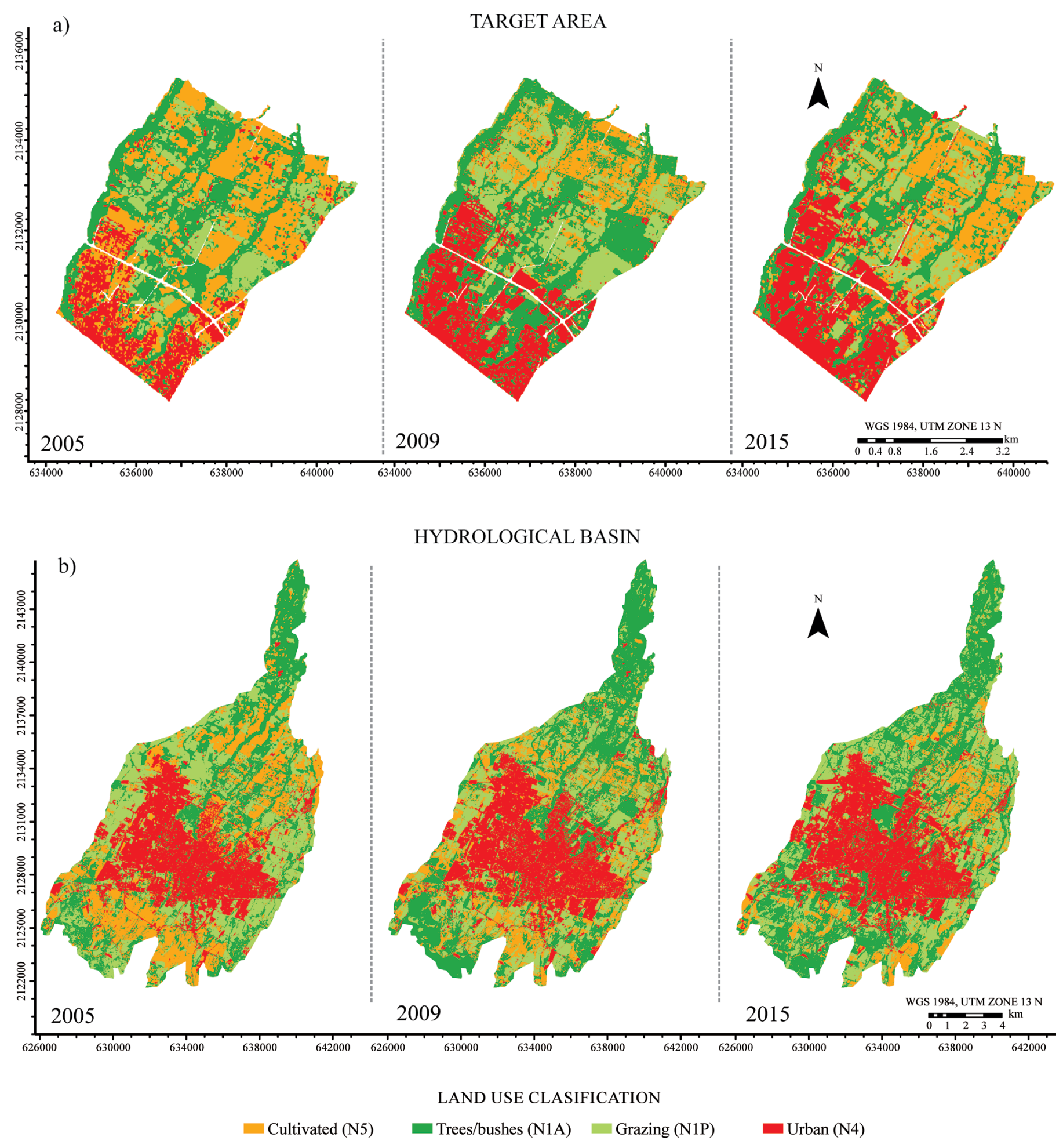

Figure 8. Land-use changes for the (a) target area, and (b) the hydrological basin (study zone).

The lowest bulk densities were found in soils from native land with trees, cultivated areas, and urban parks. Among these, cultivated soils have the highest porosity values (>50\%) due to constant agricultural plowing, resulting in a loose structure. This soil texture is in agreement with the result from the infiltration test, as the highest values of $K_{s}$ were obtained for these land use categories. In contrast, engineered soils and grazing lands show the highest bulk densities and the lowest porosities (between 5\% and 30\%) and they also correspond to the least permeable soils in the area, showing the lowest $K_{s}$ values (Tables 3 and 4). These characteristics can be easily explained considering that they are artificially (urban) or naturally (grazing) compacted.

Based on the temporal and spatial analyses of SPOT images, most 
Table 5. Land-use changes $(2005-2015)$ in the target area.

\begin{tabular}{|c|c|c|c|c|c|c|c|}
\hline \multirow{2}{*}{$\begin{array}{l}\text { Land-use } \\
\text { category }\end{array}$} & \multirow{2}{*}{$\begin{array}{l}\text { Land-use } \\
\text { symbology }\end{array}$} & \multicolumn{2}{|c|}{2015} & \multicolumn{2}{|l|}{2009} & \multicolumn{2}{|l|}{2005} \\
\hline & & $\mathrm{m}^{2}$ & $\%$ & $\mathrm{~m}^{2}$ & $\%$ & $\mathrm{~m}^{2}$ & $\%$ \\
\hline Trees/ Bushes & N1A/N1B & 7289582 & 30 & 9654295 & 39 & 8450759 & 35 \\
\hline Grazing & N1P & 4612912 & 19 & 5000194 & 20 & 3828957 & 16 \\
\hline Urban & N4 & 6744754 & 28 & 5506644 & 22 & 3686286 & 15 \\
\hline Cultivated & N5 & 5754010 & 24 & 4324825 & 18 & 8525765 & 35 \\
\hline
\end{tabular}

Total area: $24.45 \mathrm{~km}^{2}$

changes in land use correspond to urban area and cultivated land (Figure 8 ), which show an increase and a drastic decrease, respectively. This was especially true for the target area, where urban growth was evident during the 2005-2009 period. In particular, the target area is representative of the northern portion of the urban area, which is the first to receive water runoff from the basin (Figure 9). Therefore, land-use change in this area can drastically change the amount of water runoff towards the central urban area. As more permeable lands are substituted by disturbed urban soils, the infiltration capability will be reduced, increasing flooding in Colima-Villa de Álvarez metropolitan area.

\section{CONCLUSIONS AND RECOMMENDATIONS}

The change in land use in the Colima urban area is identified here as one of the factors that is increasing its susceptibility to flooding and inundation. This is especially evident in the northern sector of the city, where urban development has increased, affecting lawn infiltration rates and storm-water runoff downslope. This is mainly due to the reduction of cultivated area and, therefore, of the most permeable soils among the natural soils analyzed. These lands are being abandoned
Table 6. Land-use changes (2005 - 2015) in the hydrological basin.

\begin{tabular}{|c|c|c|c|c|c|c|c|}
\hline \multirow{2}{*}{$\begin{array}{l}\text { Land-use } \\
\text { category }\end{array}$} & \multirow{2}{*}{$\begin{array}{l}\text { Land-use } \\
\text { symbology }\end{array}$} & \multicolumn{2}{|l|}{2015} & \multicolumn{2}{|l|}{2009} & \multicolumn{2}{|l|}{2005} \\
\hline & & $\mathrm{m}^{2}$ & $\%$ & $\mathrm{~m}^{2}$ & $\overline{\%}$ & $\mathrm{~m}^{2}$ & $\%$ \\
\hline Trees/ Bushes & N1A/N1B & 60995996 & 36 & 54214220 & 32 & 43890779 & 26 \\
\hline Grazing & N1P & 47629150 & 28 & 40621971 & 24 & 50527774 & 29 \\
\hline Urban & $\mathrm{N} 4$ & 48321295 & 28 & 47723044 & 28 & 44742412 & 26 \\
\hline Cultivated & N5 & 14668708 & 9 & 29235690 & 17 & 32638753 & 19 \\
\hline
\end{tabular}

Total area: $171.73 \mathrm{~km}^{2}$

probably because they will be soon dedicated to urban development (Reddy, 2012). In addition, it is also possible that the increase in urban area is changing the local rainfall behavior, increasing the precipitation intensity (Pathiran et al., 2014) due to the urban heat island effect (Dixon and Mote, 2003), which represents one of the many consequences of land-use change (Foley et al., 2005).

It is recommended to carefully supervise the way in which the urban zone of Colima-Villa Álvarez keeps growing. It is necessary to have an adequate management of land-use change and the conservation of permeable lands in order to control flooding zones (Pedroza-Acuña et al., 2015). Neglecting studies of natural and urban environments will promote an inadequate evolution of the cities, which will put the communities of this metropolitan area at higher risk. Correct landuse management, especially in urban areas, can reduce inundation susceptibility (González-Sosa et al.,2010).

\section{ACKNOWLEDGEMENTS}

This work was supported by CONACyT 99486. Thanks to Penélope López for managing the Spot image acquisition from ERMEX-SPOT IMAGE S.A., to María Carolina Muñoz Torres for the help with the

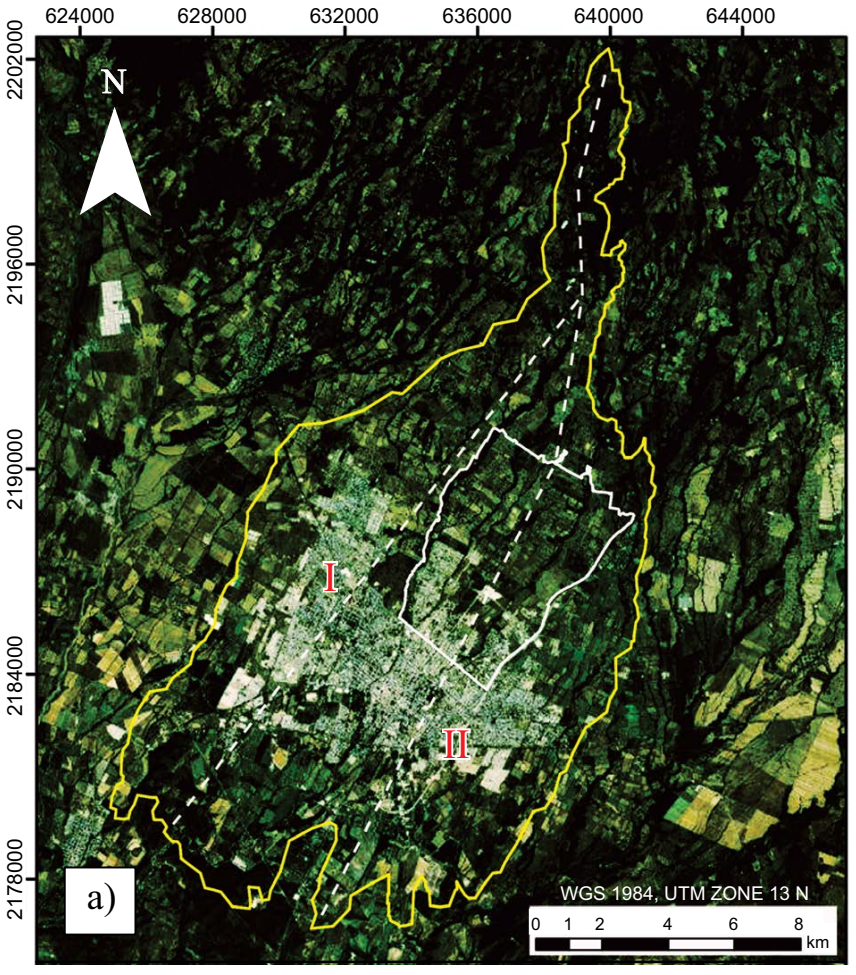

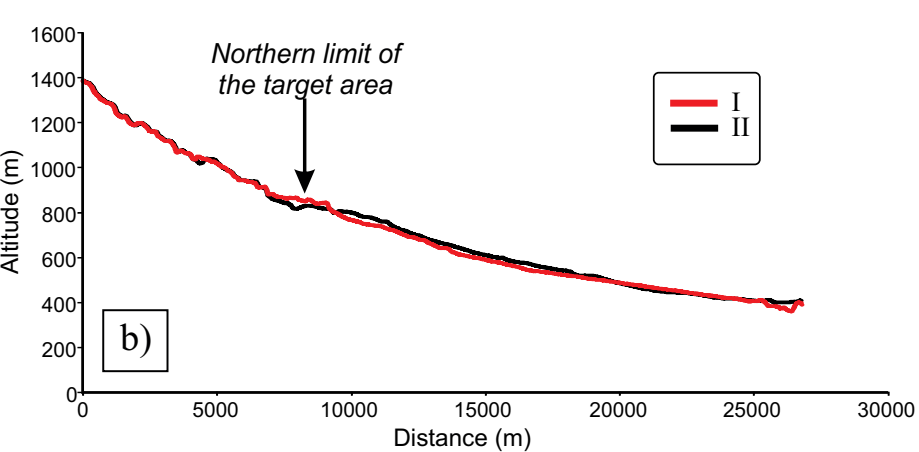

Figure 9. a) Landsat image showing the extent of the Colima hydrological basin along which two topographic profiles have been traced (I and II) to illustrate the water runoff being intersected by the northern neighborhoods of the urban zone before it drains into the metropolitan area. b) Topographic profiles showing how the urban development in the northern sector (target area) will control the amount of water runoff to the central urban area. 
laser sedimentographer analysis, to Rosario Vázquez for field-work support, and to the two reviewers of this paper; the first who wants to stay anonymous and to Blanca Prado Cano.

\section{REFERENCES}

Borselli, L., Torri, D., Poesen, J., Sanchis, P.S., 2001, Effects of water quality on infiltration, runoff and interrill erosion processes during simulated rainfall: Earth Surface Processes and Landforms, 26, 329-342.

Borselli, L., Torri, D., Poesen, J., Iaquinta, P, 2012, A robust algorithm for estimating soil erodibility in different climates: Catena, 97, 85-94.

Brady, N., 1984, Pore space of mineral soils, in Lyttleton T., Harry, O. (eds.), The Nature and properties of soils: New York, United States Agency for International Development, 52-56.

Capra, L., Gavilanes, J., Bonasia, R., Saucedo-Giron, R., Sulpizio, R. 2014, Reassessing volcanic hazard zonation of Volcán de Colima, México: Natural Hazards, 76(1), 41-61.

CENAPRED (Centro Nacional para la Prevención de Desastres), 2015, Atlas Nacional de Riesgos, Mapa de Riesgo por Inundación [National Risk Atlas, Food, risk Map] <http://rmgir.cenapred.gob.mx:8080/geonetwork/srv/es/ main.home >, fecha de consulta: 2014-2015.

Christianson, R., 2012, Impact of input data quality on storm water hydraulic modeling: Oklahoma, USA, Oklahoma State University, Ph. D. Thesis, $180 \mathrm{pp}$.

Christianson, R., Hutchinson, S., Brown, G., 2015, Curve number estimation accuracy on disturbed and undisturbed soils: Journal of Hydrologic Engineering, 21(2), 04015059.

CONAGUA (Comisión Nacional del Agua), 2015, Estaciones meteorológicas automáticas: México. D.F. <http://smn1.conagua.gob.mx/emas >, consulted 2014-2015.

Cortés, A., Garduño-Monroy, V., Navarro-Ochoa, C., Komorowski, J., Saucedo, R., Macias, J.L., Gavilanes, J., 2005. Carta Geológica del Complejo Volcánico de Colima, vol. 10, escala 1:10,000: México, D.F., Universidad Nacional Autónoma de México, Instituto de Geología, 1 mapa con texto.

Dixon, P.G., Mote, T.L., 2003, Patterns and Causes of Atlanta's Urban Heat Island- Initiated Precipitation: Journal of Applied Meteorology, 42, 1273-1284.

Dong-Shen, Y., Xue-Zheng, S., Hong-Jie, W., Xiang-Yan, Z., Weindorf, D., 2008, Function of soils in regulating rainwater in Southern China: Impacts of land uses and soils: Pedosphere, 18(6), 717-730.

Eakin, H., Lerner, A., Murtinho, F., 2010, Adaptive capacity in evolving periurban spaces: Responses to flood risk in the Upper Lerma River Valley, Mexico: Global Environmental Change, 20(1), 14-22.

Ekhmaj, A.I., Abdulaziz, A.M., 2008, Trickle irrigation as a simple tool to estimate saturated hydraulic conductivity, in Twelfth International Water Technology Conference: Alexandria, Egypt, 665-673.

Ferrer-Julia, M., Estrela, T., Sánchez del Corral, A., García-Meléndez, E., 2003, Generation of a curve number map with continuous values based on saturated hydraulic conductivity, in XI World Water Congress: Madrid, Spain, International Water Resources Association, $10 \mathrm{pp}$.

Flint, A., Flint, L., 2002, Particle density, in Dane J.H., Topp, G.C. (eds.), Methods of Soil Analysis: Sacramento, California, U.S. Geological Survey, 229-241.

Foley, J., Defries, R., Asner, G., Barford, C., Bonan, G., Carpenter, S., Stuart, F., Coe, M., Daily, G., Gibbs, H., Helkowsi, J., Holloway, T., Howard, E., Kucharik, C., Monfreda, C., Patz, J., Prentice, C., Ramankully, N., Snyder, P., 2005, Global Consequences of Land Use: Science, 309, 570-574.

Gobierno Municipal de Colima, 2012, Territorial area and Population: Gobierno Municipal de Colima: Colima, <http://www.colima.gob.mx/ ci/>, consulted: November $24^{\text {th }}, 2014$.

González-Sosa, E., Braud, I., Dehotin, J., Lassabatére, L., Angulo-Jaramillo, R., Lagouy, M., Branger, F., Jacqueminet, C., Kermadi, S., Michell, K., 2010, Impact of land use on the hydraulic properties of the topsoil in a small French catchment: Hydrological Processes, 24(17), 2382-2399.

Gregory, J.H., Dukes, M.D., Jones, P.H., Miller, G.L., 2006. Effect of Urban Soil Compaction on Infiltration Rate: Journal of Soil and Water Conservation, 61(3), 117-124.

Heiskanen, J., 1992, Comparison of three methods for determining the particle density of soil with liquid pycnometers: Communications in Soil Science and Plant Analysis, 23 (7 and 8), 841-846.

INEGI (Instituto Nacional de Estadística, Geografía e Informática), 2015, State Land and demography description: México. D.F. <http://www.inegi.org. $m x>$, consulted: March $11^{\text {th }}, 2016$.

Landscape for Life Organization, 2016, Determining soil type notes (on line): Austin Texas. USA, <http://landscapeforlife.org >: consulted: May $3^{\text {rd }}, 2016$

Leopold, L.B., 1968, Hydrology for Urban Land Planning: A Guidebook on the Hydrologic Effects of Urban Land Use: U.S. Geological Survey Circular 554, 1-19.

Luhr, J., Prestegaard, K., 1988, Caldera formation at Volcán de Colima, Mexico, by a large Holocene volcanic debris avalanche: Journal of Volcanology and Geothermal Research, 35, 335-348.

MSU (Midlands State University), 2016, Bulk density and particle density (online): Gweru. Zimbabwe, <http://www.msu.ac.zw/elearning/ material/1235306571density\%20soils.htm>, consulted: December $12^{\text {th }}$, 2015.

Nelson, D., Sommers, L., 1996, Total carbon, organic carbon, and organic matter, in Sparks, D. (ed.), Methods of Soil Analysis Part 3: Madison, Wisconsin, Soil Science Society of America and American Society of Agronomy, 961-1010.

Padilla, R., De la Parra, M., 2015, Sistematización de la recurrencia de amenazas naturales y desastres en el estado de Colima, México: Estudio Sobre las Culturas Contemporáneas, Época III, XXI, 143-165.

Pathiran, A., Denekew, H., Veerbeek, W., Zevenbergen, C., Banda, A., 2014, Impact of urban growth-driven land use change on microclimate and extreme precipitation: a sensitivity study: Atmospheric Research, 138, 59-72.

Pedroza-Acuña, A., Mejía-Estrada, I., Rodríguez-Rincón, J., DomínguezMora, R., González-Villareal, F., 2014, Flood risk from extreme events in Mexico, in $11^{\text {th }}$ International Conference on Hydroinformatics: New York, USA, CUNY Academic Works, < http://academicworks.cuny.edu/ cc_conf_hic/137>.

Pedroza-Acuña, A., Rodríguez-Rincón, J., Arganis-Juárez, M., DomínguezMora, R., González-Villareal, F., 2015, Estimation of probabilistic flood inundation maps for an extreme event: Pánuco River, México: Flood Risk Management, 8, 177-192.

Perevochtchikova, M., Lezama, J. L., 2010, Causas de un desastre: Inundaciones del 2007 en Tabasco, México: Journal of Latin American Geography, 9 (2), 73-98.

Periódico Ecos de la Costa, 2015, Árboles caídos, granizo e inundaciones en algunas vialidades, dejó lluvia ayer: Colima. México, journalistic article $<$ http://ecosdelacosta.mx $>$, consulted: July $27^{\text {th }}, 2015$.

Reddy, V., 2012, Hydrological externalities and livelihoods impacts: Informed communities for better resource management: Journal of Hydrology, 412-413, 279-290.

Romano, N., 2014, Soil moisture at local scale: Measurements and simulations: Journal of Hydrology, 516, 6-20.

Roverato, M., Capra, L., 2013, Características microtexturales como indicadores del transporte y emplazamiento de dos depósitos de avalancha de escombros del Volcán de Colima (México): Revista Mexicana de Ciencias Geológicas, 30(3), 512-525.

Sarocchi, D., Borselli, L., Macías, J.L., 2005, Construcción de perfiles granulométricos de depósitos piroclásticos por métodos ópticos: Revista Mexicana de Ciencias Geológicas, 22(3), 371-382.

SEMARNAT (Secretaría del Medio Ambiente y Recursos Naturales), 2000, Programa de Ordenamiento Ecológico y Territorial del Este de Colima: Colima, México, Gobierno Federal, Resumen Ejecutivo, 159 pp.

Silva, J., Deenik, J., Yost, R., Bruland, G., Crow, S., 2015, Improving clay content measurement in oxidic and volcanic ash soils of Hawaii by increasing dispersant concentrations and ultrasonic energy levels: Geoderma, 237238, 211-223.

Turf-Tec Internacional, 2016, Field Scout Handheld Digital Moisture Sensor (TDR 100) Manual: Florida. USA, <http://www.turf-tec.com/MSFS100lit.html>.

USDA (United States Department of Agriculture), 1999, Soil Taxonomy: Washington. USA, Natural Resources Conservation Service (NRCS), <https://www.nrcs.usda.gov/wps/portal/nrcs/main/soils/survey/class/ taxonomy/>, consulted June $22^{\text {nd }}$, 2016.

USDA (United States Department of Agriculture), 2008, Soil Quality Indicators: 
Washington. USA, Natural Resources Conservation Service (NRCS), <https://www.nrcs.usda.gov/wps/portal/nrcs/detail/soils/health/assess ment/?cid=stelprdb1237387 $>$, consulted June $14^{\text {th }}, 2016$.

Van Lagen, B.,1996, Soil Analysis, in Buurman, P., Van Lagen, B., Velthorst (eds.), Manual for soil and water analysis: Wageningen, The Netherlands, Department of Soil Science and Geology, 1-120.

White, I., Sully, M., 1987, Macroscopic and microscopic capillary length and time scales from field infiltration: Water Resources Research, 23(8), 1514-1522.

Woltemade, C. J., 2010, Impact of residential soil disturbance on infiltration rate and storm water runoff: Journal of the American water resources association, 46(4), 700-711.
Wooding, R., 1968, Steady infiltration from a shallow circular pond: Water Resources Research: 4(6), 1259-1273.

Yang, J., Zhang, G., 2015, Formation, characteristics and eco-environmental implications of urban soils - A review, in Hatana, R. (ed.), Soil science and plant nutrition: Tokyo, Taylor and Francis, 30-46.

Manuscript received: november 14, 2017

Corrected manuscript received: april 21, 2017

Manuscript accepted: may 4, 2017 